\title{
Missing in Analysis: Women in Foreign Policy-Making
}

\author{
Karen E. Smith, LSE
}

Before the end of the Cold War, only a few women had ever served as foreign minister anywhere in the world. Since the early 1990s, however, women have frequently served in this capacity, though they are still a minority in foreign policy-making. ${ }^{1}$ In September 2018, Canada and the European Union co-chaired the first ever meeting of female foreign ministers; eighteen of the almost thirty serving female foreign ministers attended, from countries spanning five continents (France24 2018).

The growing number of women in the upper echelons of foreign policy-making institutions raises an obvious question: will they make a difference to foreign policy decisions? Anne-Marie Slaughter (2012) argued that more women in top foreign policy jobs 'would change the world far more than you think, from giving peace talks a better chance to making us better able to mobilize international coalitions to reordering what issues governments even choose to work on'. Francis Fukuyama (1998) claimed that 'a world run by women would follow different rules': it would be 'less aggressive, adventurous, competitive, and violent' (p. 27). Networks have burgeoned to encourage women to consider or remain in a career in foreign affairs. ${ }^{2}$ Contemporaneously, Sweden and Canada have declared they will pursue a 'feminist foreign policy', and several states have pursued prowomen norms such as the implementation of UN Security Council Resolution 1325 (2000) on women, peace and security, and increasing women's participation in decision-making

\footnotetext{
${ }^{1} \mathrm{~A}$ list of all female foreign ministers has been compiled on Wikipedia: https://en.wikipedia.org/wiki/List of female foreign ministers $\frac{}{2}$ These include: Women's Foreign Policy Group (http://www.wfpg.org/); Women in Foreign Policy (http://www.womeninforeignpolicy.org/contact/), Foreign Policy Interrupted (http://www.fpinterrupted.com/); and one-off events such as the Global Diplomatic Forum's Women in Diplomacy 2016 conference (http://www.gdforum.org/women-in-diplomacy-2016).
} 
(Aggestam and Bergman-Rosamond 2016; Davies and True 2017; Hudson and Leidl 2015; Richey 2001). ${ }^{3}$

There is, however, very little academic literature on women in foreign policy-making and their impact on foreign policy-making including outcomes. Furthermore, there has been little use of Foreign Policy Analysis (FPA) approaches to try to investigate these questions. FPA opens the 'black box' of the state and provides explanations of how and why foreign policy decisions are made, which puts individuals and groups (from committees to ministries) at the centre of analysis. Yet the sex of decision-makers has rarely been included as a variable or factor to take into account when analysing foreign policy-making. Nor, as Anne Marie D'Aoust (2012) notes, has 'feminist foreign policy theory' developed within FPA, in contrast to the development of feminist approaches in International Relations (see also Achilleos-Sarll 2018).

This article firstly reviews such literature as there is on women and foreign policymaking. Secondly, it considers why incorporating the sex of decision-makers into FPA is problematic. Thirdly, it advocates 'gendering' FPA, which entails taking gender (and not just the sex of decision-makers) into account in the analysis of foreign policy-making (Carver 2003, 288). 'Sex' here refers to the biological categories, while 'gender' refers to beliefs about the biological categories. 'Gendered' institutions and processes reflect the privileging of 'masculine' norms over 'feminine' norms.

\section{Women and FPA: missing in analysis}

Christopher Hill defines foreign policy as 'the sum of official external relations conducted by an independent actor (usually a state) in international relations' (Hill 2016, 4). FPA is 'the examination of how foreign policy decisions are made and has assumed that the source of

\footnotetext{
${ }^{3}$ There are also groups urging states to adopt 'feminist foreign policies', such as the Centre for Feminist Foreign Policy (http://centreforfeministforeignpolicy.org/home/).
} 
much behaviour and most change in international politics is human beings, acting individually or in collectivities' (Hudson 1995, 210). International Relations (IR) theory does not seek to explain decision-making, and as such, does not focus on individuals or relatively small groups (such as bureaucracies) within states. Foreign Policy Analysis fills this gap. FPA has been described as a theory 'without a home' (Houghton 2007, 25), though arguably it complements as well as competes with the major IR approaches (Kaarbo 2015).

The various influences on foreign policy decision-making that FPA scholars typically examine include domestic factors (such as public opinion and bureaucratic politics) and international dynamics and events (from the nature of the international system to wars in other regions). The sex of decision-makers and the gendered nature of decision-making, however, have generally been ignored in FPA - despite the fact that its focus is on human beings as decision-makers.

The absence of explicit references to women, men and/or gender across the wide body of FPA literature is striking. A glance at the indexes of popular FPA textbooks reveals no entries for 'gender', 'women' or ‘men' (Alden and Aran 2016; Smith, Hadfield and Dunne 2016) - a reflection less of the authors than of the principal concerns of the discipline. Valerie Hudson $(2007,53)$ and Christopher Hill $(2016,253)$ have only brief discussions of gender and foreign policy-making. In the 80 or so issues published through the end of 2018 of the flagship journal of the discipline, Foreign Policy Analysis, only four articles deal directly with gender issues (Calin and Buterbaugh 2018; Caprioli and Douglass 2008; Davies and True 2017; Towns and Niklasson 2017), though another dozen or so either do so partially or include sex as a variable in data collection (almost entirely public opinion surveys). The very first article in Foreign Policy Analysis, by Hudson (2005), surveys the state of the FPA

\footnotetext{
${ }^{4}$ Walter Carlsnaes has argued that we must distinguish between the study of foreign policy and FPA, which is 'a particular school of research' $(2015,32)$. However, FPA is used here to cover the study of foreign policy, as is reflected in the curricula of university courses and major textbooks.
} 
literature and highlights the promising directions of contemporary FPA scholarship, but none of the work discussed involves gender. FPA is gender-free because foreign policy-making has traditionally been seen to be gender-free.

There are, however, some publications specifically on the influence women may have on foreign policy-making. The most extensive treatment of this issue is Nancy McGlen and Meredith Reid Sarkees' Women in Foreign Policy: The Insiders (1993). Principally through interviewing, they studied the experiences and attitudes of female and male policy-makers in the US, and concluded that there is little evidence that female policy-makers have a distinctly women's perspective on major issues or that adding women to foreign policy-making processes changes foreign policy outputs, although women tend to have a different, more people-centric, managerial style. The study is dated (the research was conducted in the late 1980s) but is the most comprehensive attempt to understand the role and impact of women foreign policy-makers in one national context.

More recently, Sylvia Bashevkin (2014) has examined the impact of women as senior foreign policy decision-makers in ten developed democracies, and found that in several countries, female decision-makers voiced more gender equality claims than male decisionmakers, and are associated with increased aid for women in the Global South. Michael Koch and Sarah Fulton's study of public office holders in 22 democracies shows that the 'ability of female officeholders [in security policy areas] to represent women's interests is context dependent - varying with the level of party control over legislators and the gender stereotypes that officeholders confront' (Koch and Fulton 2011, 1).

There is a growing body of research that looks at the role of particular women or groups of women serving as diplomats or in international negotiations over the past few centuries (Cassidy 2017; McCarthy 2014; Sluga and James 2016), while more recent work adds a focus on descriptive representation and gendered institutions to the study of gender 
and diplomacy (Aggestam and Towns 2018, 2019). Women in political leadership, which may include leadership on foreign policy issues, has also attracted scholarly attention (Carroll 2001; Genovese and Steckenrider 2013; Ngunjiri and Madsen 2015; Sharma 2016). This literature, however, does not focus on the process of foreign policy-making.

There has been more extensive study of the attitudes and opinions of women and men on foreign policy issues, much of which demonstrates that 'women tend to be more peaceful and less militaristic than men’ (Bjanegård and Melander 2017, 479; see also Clements 2011; Eichenberg 2019; Fite, Genex and Wilcox 1990; Togeby 1994), and that women hold more isolationist foreign policy attitudes than men (Mansfield, Mutz and Silver 2015), although these findings are not always confirmed (see Holsti and Rosenau 1981; Tessler and Warriner 1997). Several studies have also exposed a 'feminist gap': feminist men and women are more liberal on foreign policy than non-feminist men and women (Bjanegård and Melander 2017; Fite, Genex and Wilcox 1990). There is less literature on the differing attitudes of female and male policy-makers, with some studies showing differences (Bashevkin 2014) and others none (McGlen and Sarkees 1993).

Some of the work that has been done on 'gender-sensitive' policies such as gender mainstreaming (particularly in the realm of security policy and development policy) has linked such outcomes to gender-sensitive foreign policy-makers. Jacqui True has argued that one of the three factors promoting gender mainstreaming in global public policy is 'the growing numbers of feminist-oriented or gender-sensitive women and men in foreign policy and global governance leadership positions' (True 2003, p. 374). Gender-sensitive individuals are not necessarily female, as Davies and True (2017) find in the case of former British foreign secretary William Hague and his efforts to prevent sexual violence in conflict (see also work on the Clinton Administration in Garner 2013). Roberta Guerrina and Katharine A. M. Wright (2016) explain the lack of gender mainstreaming in EU external 
affairs as the absence of a 'velvet' or 'feminist' triangle, composed of 'femocrats' (individuals within a bureaucratic structure who want to work towards feminist goals), civil society organisations and epistemic communities.

Recent studies have linked the extent of gender equality in a state and that state's foreign policy (Hudson, Ballif-Spanvill, Caprioli and Emmett 2012). Brysk and Mehta (2014) find that more sexually equal countries are more likely to support international commitments against state violence against individuals, to provide more and higher quality development aid, to defend children's rights, and to support antidiscrimination measures on both sex and sexual orientation. These are significant findings, but the outcomes are not linked to the foreign policy-making process.

In sum, there is a growing body of literature that addresses, at least tangentially, the role of women in foreign policy-making. The next section considers why there has not been more literature on the effects of growing numbers of female foreign policy-makers.

\section{Challenges to focusing on women in FPA}

Foreign policy-making is patently not 'gender-free'. Taking the example only of western countries, foreign ministries were explicitly gendered from the beginning, with women long excluded outright from employment as anything other than secretaries or similar low-level positions, married women barred from working in diplomacy (for example, until 1972 in the US and 1973 in the UK), and informal rules and norms impeding women's career progression (see Crapol 1992, McCarthy 2014, McGlen and Sarkees 1993). As Ann Tickner notes, 'In the West, the image of a foreign-policymaker has been strongly associated with elite, white males and representations of hegemonic masculinity' (Tickner 2001, 54). It is implausible that this gendered institutional framework has had no effect at all on foreign policy-making 
processes or outcomes. But four analytical challenges face researchers seeking to illustrate how and why the sex of foreign policy-makers matters, and under what conditions:

1. Isolating the influence of individuals in foreign policy-making.

2. Uncovering the gendered natured of decision-making institutions and norms.

3. Identifying the differences that (rising numbers of) women in foreign policy-making may have on the process of foreign policy-making, which in turn entails identifying:

a. Whether women policy-makers have different interests, goals or values than men policy-makers;

b. Whether women policy-makers have a different way of managing or conducting processes of foreign policy-making than men policy-makers.

4. Linking the above to foreign policy outcomes.

\section{Isolating the influence of individuals}

If the sex of decision-makers matters, first it must be determined that individual decisionmakers matter. FPA is agent-centric, focusing on decision-makers. Nonetheless, individuals rarely take decisions in a vacuum, given the importance of dynamics such as groupthink or bureaucratic politics. Individuals in leadership roles - particularly presidents and prime ministers - may have a significant impact, but their influence too can be limited by institutions (formal bureaucracies, informal rules) and processes. The external context can constrain individual agency, though individuals have still been able to have a transformative influence on foreign policy.

The low numbers of women in foreign policy leadership restricts the conclusions that could be drawn about their influence, especially in large-n, comparative studies (Caprioli and Boyer 2001). However, FPA scholars isolate actors all the time, and many have focused on particular individuals such as presidents or foreign ministers. Individual agency does matter 
within foreign policy-making structures (Bashevkin 2014, 411; Herman et al 2001; Hudson 2005).

\section{Uncovering gendered institutions}

The ability of women to have an impact may depend on 'critical mass' (a threshold of women's representation often cited as 30 per cent), which only once achieved will allow women ‘to transform a previously male-dominated organization's standard operating procedures and allow women strategically to advance a feminist agenda from inside an organization' (True 2003, pp. 381-2). But critical mass theory has been criticised, and the original contribution on critical mass theory actually stated that 'critical acts' were more important (Dahlerup 2006).

A number of scholars have noted, however, that simply adding women into policymaking processes does not change either the process itself or outcomes, because change is prevented by institutionalised, gendered power structures and practices (David and Guerrina, 2013; Kantola, 2010; Weiner and MacRae 2014; Wright 2017). Work on gender and diplomacy reveals the highly gendered contexts of diplomatic sites (see McGlen and Sarkees 1993; McCarthy 2014). Socialisation within bureaucracies can limit the effect of increased numbers of women, as settled, gendered practices are accepted by relative newcomers, or the futility of challenging them is recognised. Claire Sjolander points out that 'the [Canadian] foreign service, and the Canadian foreign policy objectives which emerge from the foreign policy bureaucracy, are already gendered, and the attempt to integrate a greater number of women or to include issues concerning women and gender on the international agenda, without questioning existing practices, only serves to reinforce those practices' (Sjolander 2005, p. 29). Although in the past twenty-five years there have been three female US 
Secretaries of State, Calin and Buterbaugh (2018) find that the sex of the US Secretary of State has no effect on the appointment of female ambassadors.

\section{Identifying difference}

Another challenge is to identify whether there are relevant differences between women and men policy-makers. Some scholars criticise attempts to essentialise women and men; others start with difference, whether biologically or socially based or both.

Slaughter's argument on the beneficial impact of more women in policy-making relies on the differences between men and women, for which ' $[\mathrm{b}]$ iological and sociological explanations abound' (Slaughter 2012, 73). Fukuyama relied on a biological basis for differences between men and women to make his contentious argument about women and world politics, insisting that we should 'accept biologically grounded nature as a given' (Fukuyama 1998, 40). Cordelia Fine, however, marshals a large body of evidence to demonstrate that 'sex hasn't "fixed" any behaviours as "essential traits"” (Fine 2017, 189-90). Instead, 'the genetic and hormonal components of sex collaborate with other parts of the developmental system, including our gender constructions' (Fine 2017, 190). Altering those constructions is no easy matter because societal structures are resistant to change.

If there are differences in the attitudes and preferences of female and male policymakers, then these could stem from the gender constructions and the state of gender equality prevalent in particular societies as well as from the personal histories of the policy-makers themselves. Some research suggests that women and men differ in important respects: women are more cooperative and caring, have more empathy, are more reluctant to endorse the use of force and coercion, and are more oriented towards community standards and morals (Karpowitz and Mendelberg 2014, 19-20). Rose McDermott argues that 'all men and women are certainly influenced by both their biological reproductive goals and 
opportunities... and by their environment and the societies and cultures in which they develop' (McDermott 2014, 765-6).

Evidence for sex-based differences among foreign-policy makers so far is scant. Almost forty years ago, Ole Holsti and James Rosenau investigated whether women 'bring to the political process a set of beliefs or worldviews that differ systematically from those of their male counterparts' (Holsti and Rosenau 1981, 326). They surveyed US women in leadership positions (not foreign policy-makers) on their views of foreign policy issues (including the Vietnam War and the Cold War) and found that 'gender accounts for a rather limited amount of the variance among the American leaders in our sample' (Holsti and Rosenau 1981, 344). McGlen and Sarkees (2001) identified hardly any differences between female and male foreign policy-makers in terms of their views on particular foreign policy goals. The more recent studies by Bashevkin (2014) and Koch and Fulton (2011), though, provide some evidence for differences in views between men and women foreign policymakers.

However, there are many factors besides sex that shape individual foreign policymakers' attitudes, views, and preferences on foreign policy, including educational background; class; ethnic or racial identity; sexual orientation; position within the foreign policy machinery; and political party affiliation or preferences. These various factors will intersect with each other in particular individuals. It should not be assumed that female policy-makers as a group share the same views any more than men do so (McGlen and Sarkees 1993; Hill 2003, pp. 243-4), or that there is a foreign policy agenda (feminist or not) on which they would all agree.

Another difference between women and men could regard management or leadership style. Hannagan and Larimer (2010) argue that men and women have different behavioural patterns in decision-making processes, with men viewing it as a winner takes all process and 
women being more collaborative. The FPA literature has not really taken this possibility into consideration. For example, Hermann, Preston, Korany and Shaw (2001) have proposed that leadership style is important 'in understanding what predominant leaders will do in formulating foreign policy', but they do not make any kind of link between leadership style and the sex of the leader. The one key difference between women and men policy-makers that McGlen and Sarkees (1993) found was in fact management style, with women tending to be more consensual and people-oriented than goal-oriented. Yet others have argued that there is little agreement on whether or not women have different leadership styles to men, and that the social context is crucial (Eagly and Johannesen-Schmidt, 2001). Women may alter their leadership style to avoid or counter prejudice, and adopt perceived masculine leadership styles. Indeed a commonplace assumption is that women who have made it to the top (such as Margaret Thatcher or Indira Gandhi) have done so by 'acting like men'. They may nonetheless face gendered criticism (Hudson and Leidl 2015).

\section{Explaining outcomes}

Even if we find that there are relevant differences between men and women foreign policymakers, then it is still a challenge to uncover whether this makes a difference to policy processes, including decision-making outcomes. Does 'adding' more women as decisionmakers actually produce different outcomes? The analytical challenge is figuring out whether outcomes would indeed be different, all other factors holding constant.

A growing body of literature has sought to explain gender-sensitive policy outcomes such as: gender mainstreaming (meaning incorporating considerations of the impact of policies - including security policy - on women and men); promoting the inclusion of women in peace processes; increased levels of foreign aid; promoting human rights and in particular women's rights and children's rights; an emphasis on diplomacy and non-use of force as 
opposed to the use of force in disputes; support for peacekeeping; and, more broadly, feminist foreign policies (Aggestam and Bergman 2018). The analytical challenge, however, is linking such outcomes to the sex of policy-makers. Some research has tackled this issue. Shea and Christian (2017) found that more women legislators have a casual effect on the likelihood that a state will become involved in a humanitarian military intervention; in other words, some types of military intervention receive more support from women than others. Maledominated policy processes result in fewer gender-sensitive outcomes (Dean 2002). But as noted above, numerous actors and factors feed into foreign policy-making, and isolating women's impact on outcomes is challenging. Much of the research on gender mainstreaming found that gender-sensitive actors - male or female - are crucial.

\section{Gendering FPA}

The challenges outlined above are not necessarily insurmountable. However, a fruitful way to investigate the role of women in foreign policy-making would be to widen the scope to encompass gender and thus consider the myriad ways in which gendered contexts influence the attitudes and behaviours of individuals, and therefore affect foreign policy processes and outcomes. Gender could be explicitly incorporated into a number of FPA questions, as suggested in Table 1, and pursued through in-depth case studies, cross-country comparisons and historical research. Some indicative questions are suggested below.

\begin{tabular}{|l|l|l|}
\hline \multicolumn{2}{|l|}{ Table 1: Incorporation of gender into FPA } \\
\hline Individuals involved in & Groups (and their & Effects of individuals and \\
making & interaction with other & groups on outcomes \\
\hline Beliefs/attitudes/experiences & Interaction norms & \\
\hline
\end{tabular}




\begin{tabular}{|l|l|l|}
\hline of individuals & Decision-making norms & term) \\
Foreign policy goals & & Immediate reactions (as in a \\
Leadership styles & crisis) \\
& & \\
\hline
\end{tabular}

\section{Individuals involved in foreign policy decision-making}

Interviews with policy-makers could reveal the extent to which respondents believe there is a women's point of view on foreign policy issues, or view being a woman as a handicap in foreign policy-making processes. Other individual characteristics - such as class, race, ethnicity - intersect with gender identity so would need to be incorporated into research design. Do attitudes about gender affect views of other foreign policy-makers, including their motives and actions? Do women in policy-making roles feel that they are 'representing' women's interests (whatever those may be)?

Similarly, and following the approach adopted by Bashevkin (2014), the rhetoric used by women and men in senior foreign policy positions could be studied and compared: do they voice similar goals? Do women voice more pro-equality rhetoric than men who have served in the same position? Why do men pursue gender-sensitive outcomes?

Whether there are any differences between male and female foreign policy leaders could be investigated by adapting the schema used by Hermann, Preston, Korany and Shaw (2001) to identify whether the sex of a leader has any role at all in determining whether he or she is more goal-driven or more responsive to the political environment, challenges or respects constraints, is closed or open to information, and focuses on problems or relationships. FPA scholars could incorporate findings from the literature on women's 
leadership (Eagly and Johannesen-Schmidt 2001; Genovese and Steckenrider 2013; Ngunjiri and Madsen 2015) in which context is especially important.

\section{Groups in foreign policy-making}

Gender can also be incorporated into research on foreign policy-making groups. Recent research on the gender composition of groups provides reasons to assume that gender matters to groups, their interaction and decision-making norms, and decision outcomes. The work of Boyer et al (2009) finds that women have different negotiation behaviours though this may not necessarily affect outcomes. However, Hanagan and Larimer (2010) argue that men and women have different behavioural patterns in decision-making processes, and the gender composition of groups shapes outcomes by altering the process of how decisions are made; in particular, female-dominant groups can do a better job of locating and adopting the median outcome. Karpowitz and Mendleberg (2014) find that in groups where women have equal (or almost equal) authority to men, the group sets policies that are more generous towards the poor and vulnerable.

Although much of this work is based on experiments, with researchers observing groups of people recruited to take part in the experiments, the findings are intriguing enough to merit research into whether the same dynamics occur in foreign policy-making groups. In the real world, it would be impossible to know whether a group would have made a similar decision if the gender composition had been different. But robust research based on interviews could nonetheless take place - across time, across cases, across countries - that could seek to confirm or disprove the above-mentioned findings in the field of foreign policy.

Constructivist and feminist approaches could be used to uncover and analyse the gendered nature of norms and practices of groups in foreign policy-making. Constructivism, similar to the focus of much FPA, has a strong notion of agency: human beings can 'change 
reality' (Houghton 2007, 28). It also maintains that ideas and identity matter, and in particular that collective ideas and norms matter (Houghton 2007, 29-20). Combining constructivism with FPA would allow a 'full appreciation' of individual beliefs and socially shared norms, ideas and beliefs (Houghton 2007, 42). Such an 'appreciation' should extend to a focus on gendered norms, ideas and beliefs in foreign policy-making processes. To what extent are norms about gender roles operating in these contexts, and what are those norms? Is the language used in group decision-making still gendered (Cohn 1987)? Do these norms enable or obstruct women from having an impact on foreign policy-making? As D'Aoust $(2012,9)$ puts it, 'do diverse assumptions about femininity and masculinity affect the bureaucratic procedures and, by extension, the policy results?' Feminist institutionalism (Mackay 2011) asks these kinds of questions about the norms and practices of institutions, and can be extended to foreign policy-making institutions.

\section{Outcomes}

Another step in understanding the role that gender plays in foreign policy-making is to try to uncover the links between the actors and processes outlined above, and foreign policy outcomes. As indicated above, one approach would be to investigate the assumption that more women, and/or a less gendered process, would result in gender-sensitive policies.

Techniques such as process tracing and intensive interviewing of participants could shed light on the extent to which policy-makers identify the sex of decision-makers as a significant (or not) factor in explaining outcomes. For example, the apparent transition (or return) to 'alpha male foreign policy' (Glasser 2017) under the Trump Administration - an administration with a lower percentage of women serving than previous administrations (Lowrey and Johnson 2018) - could furnish an obvious case study. 
Finally, the role that the sex of decision-makers and gendered processes play in crisis decision-making could be taken into account. Do women and men policy-makers differ in terms of their responses to crises, and their views of how decision-making in crisis situations should be conducted? 'Defining the situation' (Kaarbo 2015, p. 205) is the critical move decision-makers make, so understanding the effect of gender on this process could help illuminate crisis decision-making. Research could build on the work of Robert Dean (2002), who examined how ingrained notions of masculinity shaped US intervention in Vietnam.

\section{Conclusion}

This article has illustrated that the sex of decision-makers and gendered decision-making processes have been remarkably absent from Foreign Policy Analysis literature. The core textbooks and flagship journal of the discipline have by and large not addressed a number of questions regarding the role that women policy-makers play in decision-making, the gendered nature of decision-making processes, and the link that these two factors have with foreign policy outcomes. FPA is largely gender-free because foreign policy-making has traditionally, but erroneously, been seen to be gender-free.

The article identified several analytical challenges facing researchers studying the role of women in foreign policy-making, including the problem of identifying whether or not there are relevant differences between women and men policy-makers such that increasing numbers of women would have an impact on the policy-making process. Taking a wider view of gender and gendered norms, institutions and processes was suggested as a starting point for investigating the impact of gender in foreign policy-making. There is much work to be done to fill our knowledge gaps about the impact of female policy-makers and gendered foreign policy processes and institutions on outcomes. 


\section{References}

Achilleos-Sarll, Columba. 2018. 'Reconceptualising Foreign Policy as Gendered, Sexualised and Racialised: Towards a Postcolonial Feminist Foreign Policy (Analysis).' Journal of International Women's Studies 19 (1): 34-49.

Aggestam, Karin and Annika Bergman-Rosamond. 2016. 'Swedish Feminist Foreign Policy in the Making: Ethics, Politics and Gender.' Ethics and International Affairs 30 (3): 323-334.

Aggestam, Karin and Ann Towns. 2018. Gendering Diplomacy and International Negotiation. London: Palgrave Macmillan.

Aggestam, Karin and Ann Towns. 2019. 'The gender turn in diplomacy: a new research agenda.' International Feminist Journal of Politics 21 (1): 9-28.Alden, Chris and Amnon Aran. 2017. Foreign Policy Analysis: New Approaches, $2^{\text {nd }}$ edition. Abingdon: Routledge.

Bashevkin, Sylvia. 2014. 'Numerical and Policy Representation on the International Stage: Women Foreign Policy Leaders in Western Industrialised Systems' International Political Science Review 35( 4): 409-29.

Bjarnegård. Elin and Erik Melander. 2017. 'Pacific men: how the feminist gap explains hostility.' The Pacific Review, 30 (4): 478-493

Boyer, Mark A., Brian Urlacher, Natalie Florea Hudson, Anat Niv-Solomon, Laura L. Janik, Michael J. Butler, Scott W. Brown and Andri Ioannou. 2009. 'Gender and Negotiations: Some Experimental Findings from an International Negotiation Simulation.' International Studies Quarterly, 53 (1): 23-47.

Brysk, Allison and Aashish Mehta. 2014. 'Do rights at home boost rights abroad? Sexual equality and humanitarian foreign policy.' Journal of Peace Research 51 (1): 97-110. 
Calin, Costel and Kevin Buterbaugh. 2018. 'Male versus Female Career Ambassadors: Is the US Foreign Service Still Biased?' Foreign Policy Analysis (online first).

Caprioli, Mary and Kimberly Lynn Douglass. 2008. 'Nation Building and Women: The Effect of Intervention on Women's Agency.' Foreign Policy Analysis 4 (1): 45-65. Carlsnaes, Walter. 2015. 'The Analysis of Foreign Policy in its Historical Context.' In The Sage Handbook of European Foreign Policy edited by Knud Erik Jørgensen, Åsne Kalland Aarstad, Edith Drieskens, Katie Laatikainen and Ben Tonra. London: Sage. Carroll, Susan J. 2001. 'Introduction.' In The Impact of Women in Public Office edited by Susan J. Carroll. Bloomington: Indiana University Press.

Carver, Terrell. 2003. 'Gender/Feminism/IR.' International Studies Review 5( 2): 288-290.

Cassidy, Jennifer, ed. 2017. Gender and Diplomacy. Abingdon: Routledge.

Clements, Ben. 2011. 'Examining Public Attitudes towards Recent Foreign Policy Issues:

Britain's Involvement in the Iraq and Afghanistan Conflicts.' Politics, 31 (2): 63-71.

Cohn, Carol. 1987. 'Sex and Death in the Rational World of Defense Intellectuals.'

Signs,12(4): 687-718.

Crapol, Edward P. ed. 1992., Women and American Foreign Policy: Lobbyists, Critics, and Insiders, $2^{\text {nd }}$ ed. Wilmington, Del: SR Books.

Dahlerup, Drude. 2006. 'The Story of the Theory of Critical Mass.' Politics and Gender, 2 (4): $511-22$.

D’Aoust, Anne Marie. 2012. 'Feminist Perspectives on Foreign Policy'. In Oxford Research Encyclopedia of International Studies. International Studies Association and Oxford University Press.

http://internationalstudies.oxfordre.com/view/10.1093/acrefore/9780190846626.001.0 $\underline{001 / \text { acrefore-9780190846626-e-179? rskey }=\text { wYaxYS\&result }=6}$. 
David, Maxine and Roberta Guerrina. 2013. 'Gender and European External Relations: Dominant Discourses and Unintended Consequences of Gender Mainstreaming.' Women's Studies International Forum, 39: 53-62.

Davies, Sara E. and Jacqui True. 2017. 'Norm Entrepreneurship in Foreign Policy: William Hague and the Prevention of Sexual Violence in Conflict.' Foreign Policy Analysis, 13 (3): 701-721.

Dean, Robert D. 2002, Imperial Brotherhood: Gender and the Making of Cold War Foreign Policy. Amherst: University of Massachusetts Press.

Eagly, Alice H. and Mary C. Johannesen-Schmidt. 2001. 'The Leadership Styles of Women and Men.' Journal of Social Issues, 57 (4): 781-97.

Eichenberg, Richard. 2019. Gender, War and World Order: A Study of Public Opinion. Ithaca: Cornell University Press.

Fine, Cordelia. 2017. Testosterone Rex: Unmaking the Myths of Gendered Minds. London: Icon.

Fite, David, Marc Genex, and Clyde Wilcox. 1990. 'Gender Differences in Foreign Policy Attitudes: A Longitudinal Analysis.' American Politics Quarterly, 18 (4): 492-513. France24. 2018. 'Foreign ministers vow to champion women's rights at first all-female summit.' 23 September 2018. https://www.france24.com/en/20180923-womenforeign-ministers-summit-canada-freeland-wallstrom

Garner, Karen. 2013. Gender and Foreign Policy in the Clinton Administration. Boulder: FirstForumPress.

Genovese, Michael A. and Janie S. Steckenrider, eds. 2013. Women as Political Leaders: Studies in Gender and Governing. Abingdon: Routledge. 
Glasser, Susan. 2017. ‘Trump’s Alpha Male Foreign Policy.’ Politico Magazine, 27

February, http://www.politico.com/magazine/story/2017/02/trumps-alpha-maleforeign-policy-214830

Guerrina, Roberta and Katharine A. M. Wright. 2016. 'Gendering Normative Power Europe: Lessons of the Women, Peace and Security Agenda.' International Affairs,92 (2): 293-312.

Hannagan, Rebecca J. and Christopher W. Larimer. 2010. 'Does Gender Composition Affect Group Decision Outcomes? Evidence from a Laboratory Experiment.' Political Behavior, 32 (1):51-67.

Hermann, Margaret G., Thomas Preston, Baghat Korany, and Timothy M. Shaw. 2001. 'Who Leads Matters: The Effects of Powerful Individuals.' International Studies Review, 3 (2): $83-131$.

Hill, Christopher. 2016. Foreign Policy in the Twenty-First Century. London: Palgrave. Holsti, Ole R. and James N. Rosenau. 1981. 'The Foreign Policy Beliefs of Women in Leadership Positions.' The Journal of Politics, 43 (2): 326-347.

Houghton, David Patrick. 2007. 'Reinvigorating the Study of Foreign Policy Decision Making: Toward a Constructivist Approach.' Foreign Policy Analysis, 3 (1): 24-45.

Hudson, Valerie with Christopher S. Vore. 1995. 'Foreign Policy Analysis Yesterday, Today and Tomorrow.' Mershon International Studies Review,39, Supplement 2: 209-238. Hudson, Valerie. 2005. 'Foreign Policy Analysis: Actor-Specific Theory and the Ground of International Relations.' Foreign Policy Analysis1 (1): 1-30.

Hudson, Valerie. 2007. Foreign Policy Analysis: Classic and Contemporary Theory. Lanham: Rowman and Littlefield.

Hudson, Valerie and Patricia Leidl. 2015. The Hillary Doctrine: Sex and American Foreign Policy. New York: Columbia University Press. 
Hudson, Valerie M., Bonnie Ballif-Spanvill, Mary Caprioli and Chad F. Emmett. 2012, Sex and World Peace. New York: Columbia University Press.

Kaarbo, Juliet. 2015. 'A Foreign Policy Analysis Perspective on the Domestic Politics Turn in IR Theory.' International Studies Review, 17 (2): 189-216.

Karpowitz, Christopher F. and Tali Mendelberg. 2014. The Silent Sex: Gender, Deliberation and Institutions. Princeton: Princeton University Press.

Koch, Michael T. and Sarah A. Fulton. 2011. 'In the Defense of Women: Gender, Office Holding, and National Security Policy in Established Democracies.' The Journal of Politics, 73 (1): 1-16.

Lowrey, Annie and Steven Johnson. 2018. 'The Very Male Trump Administration', The Atlantic, 28 March: https://www.theatlantic.com/politics/archive/2018/03/the-very$\underline{\text { male-trump-administration/556568/ }}$

Mackay, Fiona. 2011. 'Conclusion: Towards a Feminist Institutionalism?’ In Gender, Politics and Institutions, edited by Mona Lena Krook and Fiona Mackay. Houndmills: Palgrave Macmillan.

Mansfield, Edward D. Diana C. Mutz, and Laura R. Silver. 2015. 'Men, Women, Trade and Free Markets.' International Studies Quarterly, 59 (2): 303-315.

McCarthy, Helen. 2014. Women of the World: The Rise of the Female Diplomat. London: Bloomsbury.

McDermott, Rose. 2014. 'Sex and Death: Gender Differences in Aggression and Mottivations for Violence.' International Organization, 69 (3): 753-75.

McGlen, Nancy E. and Meredith Reid Sarkees. 1993. Women in Foreign Policy: The Insiders London: Routledge.

Ngunjiri, Faith Wambura and Susan R. Madsen, eds. 2015. Women as Global Leaders. Charlotte, NC: Information Age Publishing. 
Richey, Lisa Ann. 2001. 'In Search of Feminist Foreign Policy: Gender, Development and Danish State Identity.' Cooperation and Conflict, 36 (2): 177-212.

Shea, Patrick E. and Charlotte Christian. 2017. 'The Impact of Women Legislators on Humanitarian Interventions.' Journal of Conflict Resolution, 61 (10): 2043-73.

Sharma, Dinesh, ed. 2016. The Global Hillary: Women's Political Leadership in Cultural Contexts. Abingdon: Routledge.

Sjolander, Claire Turenne. 2005. 'Canadian Foreign Policy: Does Gender Matter?' Canadian Foreign Policy Journal, 12 (1): 19-31.

Slaughter, Anne-Marie. 2012. 'Why Family is a Foreign-Policy Issue Too.' Foreign Policy, December: 73 .

Sluga, Glenda and Carolyn James, eds. 2016. Women, Diplomacy and International Politics Since 1500. Abingdon: Routledge.

Smith, Steve, Amelia Hadfield, and Tim Dunne, eds. 2016. Foreign Policy: Theories, Actors, Cases, $3^{\text {rd }}$ edition. Oxford: Oxford University Press.

Tessler, Mark and Ina Warriner. 1997. 'Gender, Feminism and Attitudes toward International Conflict: Exploring Relationships with Survey Data from the Middle East.' World Politics, 49 (2): 250-81.

Tickner, Ann. 2001. Gendering World Politics. New York: Columbia University Press.

Togeby, Lise. 1994. 'The Gender Gap in Foreign Policy Attitudes', Journal of Peace Research, 31 (4): 374-392.

Towns, Ann and Birgitta Niklasson. 2017. 'Gender, International Status and Ambassador Appointments.' Foreign Policy Analysis, 13 (3): 521-540.

True, Jacqui. 2003. 'Mainstreaming Gender in Global Public Policy.' International Feminist Journal of Politics, 5 (3): 368-96. 
Weiner, Elaine and Heather MacRae. 2014. 'The Persistent Invisibility of Gender in EU

Policy: Introduction.’ European Integration Online Papers (EIoP), 18, Special issue 1: 1-20, http://eiop.or.at/eiop/texte/2014-003a.htm.

Wright, Hannah. 2017. 'Gender in policymaking is about more than counting women.' LSE blog Women in Peace and Security, 3 August 2017, http://blogs.lse.ac.uk/wps/2017/08/03/gender-in-policymaking-is-about-more-thancounting-women/ 